\title{
Factors Affecting Infection of Yellow Starthistle (Centaurea solstitialis) by Synchytrium solstitiale, Causal Agent of False Rust Disease
}

\author{
T. L. Widmer, Research Plant Pathologist, and F. Guermache, Technician, European Biological Control Laboratory, \\ United States Department of Agriculture-Agricultural Research Service, Campus International de Baillarguet, CS \\ 90013, Montferrier sur Lez, 34988 St. Gely du Fesc Cedex, France
}

\begin{abstract}
Widmer, T. L., and Guermache, F. 2006. Factors affecting infection of yellow starthistle (Centaurea solstitialis) by Synchytrium solstitiale, causal agent of false rust disease. Plant Dis. 90:425-428.

Yellow starthistle (Centaurea solstitialis) is an annual invasive weed in the United States with Mediterranean origins. The expense of chemical control and the vast area of invasion make this weed an appropriate target for classical biological control. Observations of a field site in southern France revealed small orange galls on the leaves of yellow starthistle seedlings caused by the fungus Synchytrium solstitiale. Inoculation of yellow starthistle seedlings with a suspension of zoospores released from infected tissue resulted in infection. Ten days after inoculation, typical orange galls appeared on the exposed tissue. Preliminary host range testing showed up to $100 \%$ infection of $C$. solstitialis seedlings from both France and the United States and infection of Carthamus tinctorius, Centaurea americana, C. diffusa, C. rothrockii, C. squarrosa, and Helianthus annuus seedlings. No symptoms were observed on seedlings of Centaurea calcitrapa, C. maculosa, C. sulfurea, Cirsium californica, C. occidentale, Cynera cardunculus, and Taraxacum officinale. Zoospores were released in a $\mathrm{pH}$ range between 4.45 and 8.25 and optimally at temperatures between 5 and $15^{\circ} \mathrm{C}$. Infection of yellow starthistle seedlings occurred after a minimum 1-h exposure to a zoospore suspension at $20^{\circ} \mathrm{C}$.
\end{abstract}

Centaurea solstitialis L. (Asteraceae), common name yellow starthistle, is an invasive weed originating in the Mediterranean region (19). Although not considered noxious or of significant impact in its native territory, it is considered a noxious weed in Australia, Chile, South Africa, and the United States. Yellow starthistle adapts to a wide range of conditions and tolerates a variety of soil types. It can survive and spread in regions receiving as little as 254 $\mathrm{mm}$ of precipitation each year (2). In the United States, yellow starthistle is a serious pest of pastures, rangelands, croplands, natural areas, and recreational areas, spreading quickly if left uncontrolled. In dense pasture stands, it displaces native vegetation and replaces desirable forage, thereby reducing effective grazing time. In addition, consumption of yellow starthistle causes "chewing disease" in horses, which may be fatal (3). The spiny flowerheads also reduce the use of recreational areas. It is estimated that yellow starthistle produces an estimated 1,400 to 13,000

Corresponding author: T. L. Widmer

E-mail: tlwidmer@ars-ebcl.org

Accepted for publication 25 October 2005.

DOI: 10.1094/PD-90-0425

This article is in the public domain and not copyrightable. It may be freely reprinted with customary crediting of the source. The American Phytopathological Society, 2006. $\mathrm{seed} / \mathrm{m}^{2}(17)$ and spreads at a rate of about 2,800 to $8,000 \mathrm{ha} / \mathrm{year}$ in the United States (2).

Herbicides and cultural methods such as burning and grazing can be effective in managing yellow starthistle, but these methods are costly and labor intensive (19). Efforts have been continuing for numerous years to find and develop biological control agents for this weed. Several insects already have been released that show some management in certain areas, but are not completely satisfactory $(16,20)$. Until recently, no effective pathogens have been found that inflict significant damage to yellow starthistle under natural conditions. One pathogen, a rust identified as Puccinia jaceae var. solstititialis, was described in 1970 on C. solstitialis (18) and has been developed as a potential biological control agent (1). It has now gained States to manage yellow starthistle (W. Bruckart, Fort Detrick, MD, personal communication). However, the research needed to demonstrate that an exotic pathogen is safe for release in the United States requires considerable time. Therefore, it is necessary to continually search for and investigate new agents that have potential for release in the future.

In December 2000, symptoms of a new disease were observed first on yellow starthistle seedlings in France. The symptoms observed were small orange galls approval for field release in the United containing sporangia embedded within the stems of the seedlings at or near the soil line. By February 2001, when the yellow starthistle plants were in the rosette stage, the same symptoms were observed on the leaves along the midrib and within the trichomes. Resting spores formed throughout the cycle, but were most abundant in March and April. After April, when the plant starts to bolt and the rosette leaves senesce, the symptoms and the fungus were no longer observed. The disease cycle started again in late October when the yellow starthistle seedlings germinate. The disease has been observed consistently each year in the same location. The causal agent was identified as Synchytrium solstitiale Widmer (22). The objective of this study was to investigate the conditions for infection and conduct a preliminary host range study.

\section{MATERIALS AND METHODS}

Fungal material. Orange galls on $C$. solstitialis, containing sporangia of $S$. solstitiale, were collected at a site near $\mathrm{Ca}$ zevieille, France $\left(43^{\circ} 43^{\prime} 29^{\prime \prime} \mathrm{N}, 3^{\circ} 47^{\prime} 42^{\prime \prime}\right.$ E) where natural infection occurs. The leaf material was surface sterilized by immersing the leaves in $50 \mathrm{ml}$ of $75 \%$ ethanol plus 2 drops of Tween 20 (Sigma Chemical Co., Saint Quentin Fallavier, France) for $30 \mathrm{~s}$. The leaves were transferred to $0.5 \%$ calcium hypochlorite for $20 \mathrm{~min}$ and then rinsed three times in sterile distilled water for $10 \mathrm{~min}$ each time. The leaves were blotted dry and placed in an enclosed petri plate containing a moist paper towel at $5^{\circ} \mathrm{C}$ until needed.

Temperature effect on zoospore release and infection. Two segments (each approximately $5 \mathrm{~mm}^{2}$ ) of heavily infected yellow starthistle tissue were placed in a plastic well containing $0.5 \mathrm{ml}$ of sterile distilled water plus streptomycin at 100 $\mathrm{mg} / \mathrm{liter}$. An attempt was made to place an equal amount of sori within the tissue in each well. On average, each infected segment contained 90 sori. The wells were covered and placed in the dark at temperatures of $5,10,15,20,25,30$, or $37^{\circ} \mathrm{C}$. There were two repetitions per temperature. After $24 \mathrm{~h}$, the zoospores were subjected to a vortex to induce encystment and counted with a hemacytometer. The repetitions were averaged for each temperature. The experiment was repeated four times. The standard deviation for each temperature was calculated from the means of the 
replications. Data were subjected to analysis of variance using GLM and the means were compared statistically using least significant differences.

To determine the impact of temperature on infection timing, two segments of heavily infected yellow starthistle tissue each were placed in three plastic wells containing $0.5 \mathrm{ml}$ of sterile distilled water plus streptomycin at $100 \mathrm{mg} / \mathrm{liter}$. The wells were covered and placed in the dark in an incubator at $10^{\circ} \mathrm{C}$. Six hours after zoospores were released, yellow starthistle seedlings with true leaves just emerging were submerged into the solutions to expose the leaves and placed in incubators at $5,10,15,20,25,30$, or $37^{\circ} \mathrm{C}$. Three seedlings were removed $1,2,4,6,8,12$, or 24 $\mathrm{h}$ after submersion and exposure to the zoospores and planted in vermiculite. The plants were kept in an incubator at $15^{\circ} \mathrm{C}$ and observed for symptoms. The number of infected seedlings was noted. The experiment was repeated twice for each temperature. To determine any differences between the experiments, the data were subjected to analysis of variance using GLM and the means were compared statistically using least significant differences.

pH effect on zoospore release. Stock solutions of McIlvaine buffer of various $\mathrm{pH}$ were prepared as described by McIlvaine (13) by varying the ratios of $0.1 \mathrm{M}$ citric acid and $0.2 \mathrm{M}$ disodium hydrogen phosphate. Dilutions of McIlvaine buffer with a final $\mathrm{pH}$ range between 3.20 and 9.10 were prepared by adding $1 \mathrm{ml}$ of stock McIlvaine buffer to $49 \mathrm{ml}$ of distilled water. Two segments (each approximately $5 \mathrm{~mm}^{2}$ ) of heavily infected yellow starthistle tissue were placed in a plastic well containing $0.5 \mathrm{ml}$ of sterile diluted McIl- vaine buffer at each $\mathrm{pH}$. The wells were covered and placed in the dark at $10^{\circ} \mathrm{C}$. There were two repetitions for each $\mathrm{pH}$. After $6 \mathrm{~h}$, the solutions were recorded for active zoospore release, nonmotile zoospore release, or no zoospore release. The experiment was repeated once.

Pathogenicity tests and preliminary host range. Two methods were used for artificial inoculation of young seedlings. The first method involved cutting naturally infected tissue with sporangia into segments approximately $3 \mathrm{~mm}^{2}$ and placing the segments directly on the apical meristem of 10-day-old yellow starthistle seedlings planted in plastic cups containing autoclaved vermiculite. Seedlings were misted with water using a hand sprayer and the top of the cup was covered with a clear plastic lid to retain moisture. The seedlings were placed in an incubator at $15^{\circ} \mathrm{C}$ with a $16-\mathrm{h}$ photoperiod and $11^{\circ} \mathrm{C}$ with an 8-h dark period. The plants were misted every 2 days. The experiment was repeated three times, with 10 plants inoculated each experiment.

For the second artificial inoculation method, naturally infected tissue with sporangia was cut into segments approximately $3 \mathrm{~mm}^{2}$ and placed in a glass well (2-ml volume) containing $0.5 \mathrm{ml}$ of water plus streptomycin (100 mg/liter). The glass wells were placed in a glass petri dish (100 $\mathrm{mm}$ in diameter) with moistened filter paper. Ten-day-old yellow starthistle seedlings were placed in the glass well so that the apical meristem tissue and cotyledons were slightly immersed in the suspension. The covered petri dish was placed in an incubator at $15^{\circ} \mathrm{C}$ with a 16 -h photoperiod and $11^{\circ} \mathrm{C}$ with an 8 -h dark period. After 24 $\mathrm{h}$, the seedlings were removed and planted

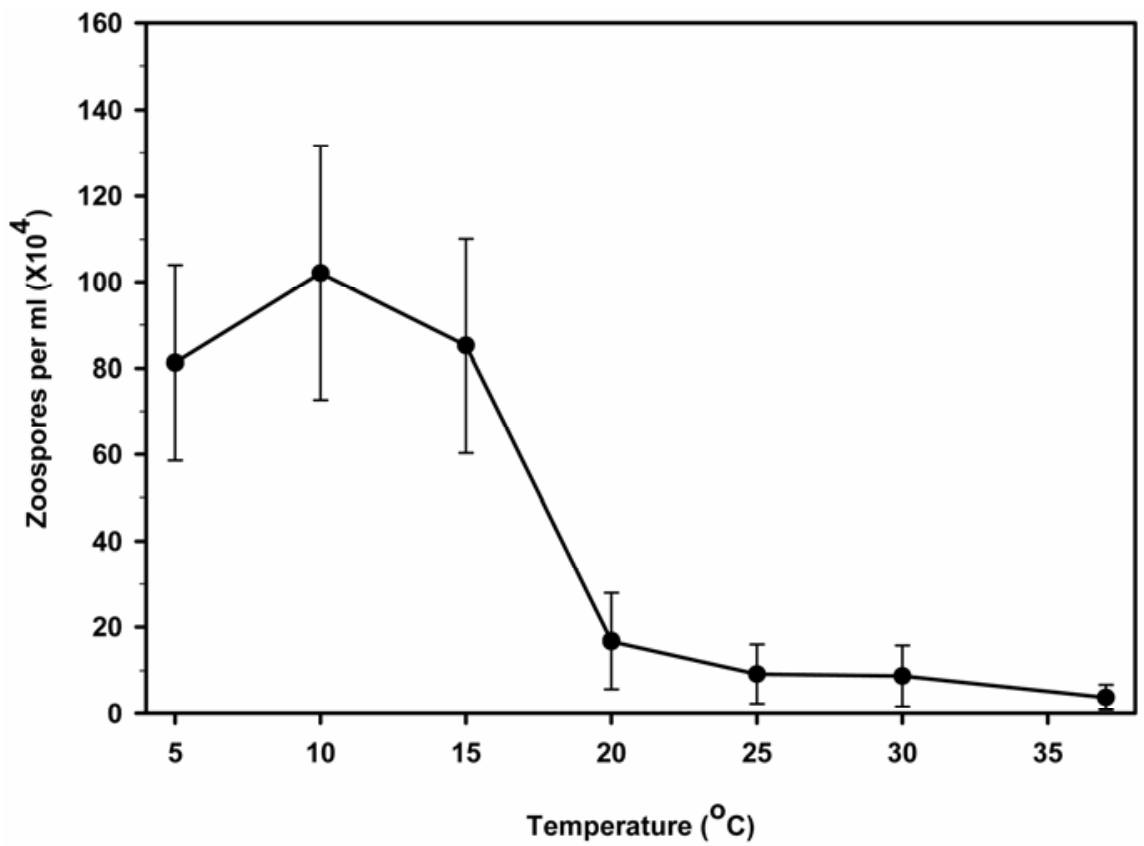

Fig. 1. Effect of temperature on release of Synchytrium solstitiale zoospores after $24 \mathrm{~h}$. Bars represent standard error of the means. in plastic pots containing autoclaved vermiculite. Seedlings were misted with a hand sprayer and the top of the cup was covered with a clear plastic lid to retain moisture. The seedlings were placed in the incubator under the same conditions as above. The plants were misted every 2 days. The experiment was repeated three times, with 10 plants inoculated in each experiment. Data were subjected to analysis of variance using GLM. The percentage of infection means of the two methods were compared statistically using least significant differences.

Seed of Carthamus tinctorius, Centaurea americana, C. calcitrapa, C. diffusa, C. maculosa, C. rothrockii, C. solstitialis (from France and California), $C$. squarrosa, C. sulfurea, Cirsium californica, C. occidentale, Cynara cardunculus, Helianthus annuus, and Taraxacum officinale were germinated on moist filter paper in a petri plate. Using the second inoculation method described above, at least 10 seedlings with the first true leaf just emerging from each of the plants were exposed to a suspension of zoospores with a concentration of at least $7 \times 10^{3}$ zoospores $/ \mathrm{ml}$. The seedlings were transplanted after $72 \mathrm{~h}$ in autoclaved vermiculite and placed in an incubator at $15^{\circ} \mathrm{C}$ with a $16-\mathrm{h}$ photoperiod and $11^{\circ} \mathrm{C}$ with an 8 -h dark period. Plants were misted every 2 days with water and observed for symptoms after 10 days. The experiment was repeated once.

\section{RESULTS}

Temperature effect on zoospore release and infection. Zoospores were released within $6 \mathrm{~h}$ at all temperatures measured. After $24 \mathrm{~h}$, the number of zoospores released for each temperature are shown in Figure 1. The optimum temperature for zoospore release was $10^{\circ} \mathrm{C}$ but was not significantly different from the number released at 5 or $15^{\circ} \mathrm{C}(P=0.835)$.

At each temperature and time combination, not all exposed seedlings were infected, but there was not a significant difference in the infection rate within the combinations between experiments $(P=$ 0.763). Infection of the yellow starthistle seedlings occurred at temperatures from 5 to $20^{\circ} \mathrm{C}$ (Table 1 ). At $20^{\circ} \mathrm{C}$, infection occurred within $1 \mathrm{~h}$ of exposure, which was the earliest time measured, and within $4 \mathrm{~h}$ at 10 and $15^{\circ} \mathrm{C}$. No infection occurred at temperatures of 25,30 , or $37^{\circ} \mathrm{C}$. After 24 $\mathrm{h}$, zoospores were still very active at temperatures between 5 and $20^{\circ} \mathrm{C}$, but no zoospore motility was observed after $1 \mathrm{~h}$ of exposure to temperatures of 25,30 , or $37^{\circ} \mathrm{C}$.

pH effect on zoospore release. The observations made on the impact of zoospore release and motility showed no differences between repetitions and between experiment at each pH. After $6 \mathrm{~h}$, active zoospores were observed in the solutions with 
a $\mathrm{pH}$ between 4.45 and 8.25 (data not shown). A few cysts or nonmotile zoospores with the flagellum still attached were observed at $\mathrm{pH} 3.503 .75,4.15,4.30$, and 8.65. No zoospores were observed in solutions with a pH of $3.15,3.35$, and 9.10 .

Pathogenicity tests and preliminary host range. Both artificial inoculation methods resulted in the development of orange galls on the meristematic tissue of young yellow starthistle seedlings after 10 days. Zoospores were observed in the water containing sporangia $5 \mathrm{~h}$ after immersion. An infection rate between 70 and $100 \%$ occurred on yellow starthistle seedlings exposed to the inoculum using the two methods described above. There was no statistical difference in the percentage of infected plants between the two methods $(P=0.372)$.

In the host range study, the data from both experiments were combined. Approximately $95 \%$ of the Centaurea solstitialis seedlings from both France and the United States became infected. Carthamus tinctorius, Centaurea americana, C. diffusa, C. rothrockii, $C$. squarrosa, and $H$. annuus seedlings also were infected at rates of 10 , $10,70,25,70$, and $7 \%$, respectively. No symptoms were observed on Centaurea sulfurea, C. muclosa, C. calcitrapa, Cirsium californica, C. occidentale, Cynara cardunculus, or T. officinale seedlings.

\section{DISCUSSION}

This fungus, which causes a false rust on yellow starthistle (22), recently was described as a new species and named $S$. solstitiale. In that study, histological sections revealed two distinct structures within the tissue, sporangia and thickwalled resting spores. Infection of seedlings was observed only through sporangial release of zoospores. Resting spores are important in survival and proliferation in the following year by releasing zoospores as reported in other species $(9,14)$ because sporangia are not observed in the tissue after early spring.

Although the optimum temperature for infection occurred with the least exposure time at $20^{\circ} \mathrm{C}$ (Table 1). Infection did not occur above $20^{\circ} \mathrm{C}$, which most likely is related to the observation that no zoospores were observed to be active when zoospore release was between 5 and $15^{\circ} \mathrm{C}$,

exposed to temperatures of $25^{\circ} \mathrm{C}$ and above. Although not specifically examined, these results suggest that germination and penetration of encysted zoospores cannot occur by random settling on the leaf tissue.

$S$. solstitiale is being investigated as a potential biological control agent against yellow starthistle. One important criterion for a biological control agent is host specificity. Karling (9) stated that some species of Synchytrium have narrow whereas others have broad host ranges. Species such as $S$. decipiens and $S$. taraxaci appear to be limited to a single host genus whereas others, such as $S$. endobioticum and $S$. fulgens, are limited to hosts in the families Solanaceae and Onagraceae, respectively. In contrast, $S$. aureum has been reported on at least 198 species in 34 families of flowering plants. The number of hosts tested in this study revealed that four other Centaurea spp. are susceptible to $S$. solstitiale, whereas three others are not. It is significant that $T$. officinale was not infected because it is reported to be infected by $S$. taraxaci, the only other Synchytrium sp. in the same subgenus as $S$. solstitiale (9). In nature, no other plant species were observed to be infected in the vicinity of the discovered pathogen (data not shown).

Three other members of the tribe Cardueae in the Asteraceae outside the genus Centaurea were tested in this study, with infection only on Carthamus tinctorius (safflower). This suggests a potential host range outside the genus Centaurea. Outside the tribe Cardueae, only one species tested, H. annuus, became infected, and infection was observed only on one cotyledonary leaf. Although infection of safflower occurred, this agent still could be pursued as a biological control agent. Infection of yellow starthistle in the field is most severe from November through February, with some in March. In California, safflower is a field crop that generally is not planted until March and even in late May (7). In the Sacramento Valley and the San Joaquin Valley, where most of the safflower is grown in California, the average monthly rainfall in March is 5 and 5.5 $\mathrm{cm}$, respectively and, in April, is 4 and 2 $\mathrm{cm}$, respectively. Although no study has been done to determine the amount of moisture needed to maintain and induce epidemics of this disease in a defined area,

Table 1. Infection of Centaurea solstitialis seedlings by Synchytrium solstitiale zoospores after exposure for various times at different temperatures

\begin{tabular}{lccccccc}
\hline & \multicolumn{7}{c}{ Exposure time (h) } \\
\cline { 2 - 8 } Temperature $\left({ }^{\mathbf{0}} \mathbf{C}\right)$ & $\mathbf{1}$ & $\mathbf{2}$ & $\mathbf{4}$ & $\mathbf{6}$ & $\mathbf{8}$ & $\mathbf{1 2}$ & $\mathbf{2 4}$ \\
\hline 5 & - & - & - & + & + & + & + \\
10 & - & - & + & + & + & + & + \\
15 & - & - & + & + & + & + & + \\
20 & + & + & + & + & + & + & + \\
25 & - & - & - & - & - & - & - \\
30 & - & - & - & - & - & - & - \\
37 & - & - & - & - & - & - & - \\
\hline
\end{tabular}

a Symptoms observed (+) and no symptoms (-). field observations indicate that infection on individual plants was reduced when winter rainfall was low. Infection of safflower by S. solstitiale is expected to be minor during this time period in California because moisture appears to be a key factor in pathogenicity and spread. Further tests also should be conducted to demonstrate the speed and distance that this fungus would move because active zoospores are the only method for infection.

The fungi in this order (Chytridiales) often have resting spores that survive up to 30 years in the soil $(10,12)$. This would be ideal for a biological control agent, whereby a single release could have longlasting effectiveness. However, the fact that it is an obligate parasite limits mass production of sufficient quantities for a large-scale release. Because of this limitation of mass production, the impact of this fungus on populations of yellow starthistle will be a key consideration in determining whether or not this fungus is worth pursuing as a biocontrol agent. Other host studies $(4,5,8,11,15,21)$ involving various Synchytrium spp. have reported stunting in growth and lower seedling survival in infected plants, which suggests that this fungus can negatively impact the growth of yellow starthistle. Currently, research is being conducted to study the impact on growth in the field under natural infection conditions. More work is needed, including epidemiology, development of mass propagation, perhaps through the use of tissue culture and cell suspensions (6), and a more thorough host specificity study, to determine whether or not this fungus can be used as a biocontrol agent to manage $C$. solstitialis.

\section{LITERATURE CITED}

1. Bruckart, W. L. 1989. Host range determination of Puccinia jaceae from yellow starthistle. Plant Dis. 73:155-160.

2. Callihan, R. H., Northam, F. E., Johnson, J. B., Michalson, E. L., and Prather, T. S. 1989. Yellow starthistle control. Univ. Idaho Curr. Inf. Ser. 634 .

3. Cordy, D. R. 1978. Centaurea species in equine nigropallidal encephalomalacia. Pages 327-336 in: Proc. IX Int. Symp. Biol. Control of Weeds. R. F. Keller, K. R. Van Kampen, and L. F. James, eds. University of Cape Town, South Africa.

4. de Vera-Chaston, H. P. 1977. Synchytrium psophocarpi (Rac.) Gaumann, its development and anatomy of infection on Psophocarpus tetragonolobus (L.) DC. Philipp. J. Biol. 6:183-198.

5. Drinkall, M. J., and Price, T. V. 1986. Studies of the infection of the winged bean by Synchytrium psophocarpi in Papua New Guinea. Ann. Appl. Biol. 109:87-94.

6. Ingram, D. S. 1971. An attempt to establish dual cultures of Synchytrium endobioticum and Solanum tuberosum callus. Phytopathol. Z. 71:21-24.

7. Kaffka, S. R., and Kearney, T. E. 1998. Safflower production in California. Univ. Calif. Agric. Nat. Resour. Publ. 21565.

8. Karamchandani, D. 1987. The economic importance of plant health in Canada: the case of the golden nematode and potato wart. Food Comment. 9:16-27. 
9. Karling, J. S. 1964. Synchytrium. Academic Press, New York.

10. Laidlaw, W. M. R. 1985. A method for detection of the resting sporangia of potato wart disease (Synchytrium endobioticum) in the soil of old outbreak sites. Potato Res. 28:223-232.

11. Lenné, J. M., Torres, C., and Garcia, C. 1990. Effect of wart disease on survival and yield of the tropical pasture legume Desmodium ovalifolium. Plant Dis. 74:676-679.

12. McDonnell, M. G., and Kananagh, J. A. 1980. Studies on Synchytrium endobioticum (Schilb.) Perc. in Ireland. J. Life Sci. R. Dublin Soc. $1: 177-182$.

13. McIlvaine, T. C. 1921. A buffer solution for colorimetric comparison. J. Biol. Chem. 49:183186.

14. Raghavendra Rao, N. N., and Pavgi, M. S. 1978. Perpetuation of Synchytrium species parasitic on cucurbits. Indian J. Agric. Sci.
48:76-78.

15. Raghavendra Rao, N. N., and Pavgi, M. S. 1979. Germination of resting spores in Synchytrium species parasitic on Cucurbitaceae. Mycopathologia 69:3-10.

16. Rees, N. E., Quimby, P. C., Jr., Piper, G. L., Coombs, E. M., Turner, C. E., Spencer, N. R., and Knutson, L. V. 1995. Biological Control of Weeds in the West. Society of Weed Science, United States Department of Agriculture, Agricultural Research Service, Montana Department of Agriculture, Montana State University, Bozeman.

17. Roché, C. T., and White, G. R. 2000. Managing yellow starthistle in Southwestern Oregon. Oreg. State Univ. Bull. EM 8750.

18. Savile, D. B. O. 1970. Some Eurasian Puccinia species attacking Cardueae. Can. J. Bot. 48:1533-1566.

19. Sheley, R. L., Larson, L. L., and Jacobs, J. S.
1999. Yellow starthistle. Pages 408-416 in: Biology and Management of Noxious Rangeland Weeds. R. L. Sheley and J. K. Petroff, eds. Oregon State University Press, Corvallis.

20. Turner, C. E., Johnson, J. B., and McCaffrey, J. P. 1995. Yellow starthistle, Centaurea solstitialis L. (Asteraceae). Pages 270-275 in: Biological Control in the Western United States: Accomplishments and Benefits of Regional Research Project W-84, 1964-1989. J. R. Nechols, L. A. Andrews, J. W. Beardsley, R. D. Goeden, and C. G. Jackson, eds. Univ. Calif. Div. Agric. Natl. Res. Publ. 3361.

21. Variar, M., and Pavgi, M. S. 1979. Resistance of germinating zoosporangia of Synchytrium sesamicola to heat and desiccation. Phytopathol. Mediterr. 18:201-202.

22. Widmer, T. L. 2004. Synchytrium solstitiale $\mathrm{sp}$. nov. causing a false rust on Centaurea solstitialis in France. Mycologia 96:407-410. 